\title{
Performance, Carcass Traits, and Body Composition of Broilers Fed Different Linseed Oil Levels between 21 and 56 Days of Age*
}

\section{-Author(s)}

\section{KF Duartel}

OM Junqueira"

LL Borges'

E Rodrigues

R da S Filardiv

MFFM Praes'

AC de Laurentiz ${ }^{N}$

$\mathrm{CH}$ de F Domingues'

Departamento de Zootecnia da Universidade Estadual Paulista, Faculdade de Ciências Agrárias e Veterinárias FCAV/ UNESP Jaboticabal

" Departamento de Zootecnia da Universidade Federal de Goiás - UFG - Campus Jataí

III Instituto Federal de Educação, Ciência e Tecnologia do Triangulo Mineiro - IFTMCampus Uberaba

Iv Departamento de Biologia e Zootecnia da Universidade Estadual Paulista Júlio de Mesquita Filho, Faculdade de Engenharia de llha Solteira - UNESP

\section{Mail Adress}

Corresponding author e-mail address Karina Ferreira Duarte

Rua Anhanguera, 140, Recreio dos Bandeirantes, Jaboticabal-SP, CEP 14883414

E-mail: karinafduarte@yahoo.com.br

\section{nKeywords}

Ether extract, weight gain, abdominal fat, crude protein, carcass yield.

-Process FAPESP 2009/50831-0

\section{ABSTRACT}

This study was carried out to evaluate the effect of the inclusion of different linseed oil levels $(0.0,3.3,6.6$, or $9.9 \%)$ in iso-energy diets fed during the period of 21 to 56 days of age on the performance, carcass traits, and body composition of broilers. A total of 1,600 broilers were distributed according to a completely randomized experimental design consisting of four treatments with eight replicates of 40 birds per experimental unit. In the period of 21-42 days of age, weight gain increased, feed and calorie conversion ratios quadratically improved, and feed and metabolizable energy intakes linearly increased as dietary linseed oil level increased. Considering the entire experimental period, dietary linseed oil linearly increased weight gain and feed and energy intakes, and feed and calorie conversion ratios in a quadratic manner. On days 42 and 56, abdominal fat percentage and carcass yield were quadratically influenced by dietary linseed oil. Total body fat content at 56 days of age was quadratically influenced by dietary linseed levels.

\section{INTRODUCTION}

Dietary fat addition enhances broilers performance in terms of feed intake (López-Ferrer et al., 2001a), weight gain (Ajuyah et al., 1991; Rodríguez et al., 2005), and feed conversion ratio (Dvorin et al., 1998). Improvements in body composition and meat characteristics have also been reported (Sanz et al., 1999; Crespo \& Esteve-Garcia, 2001). Its advantages under heat stress are attributed to the low heat increment of fat digestion and absorption (Dale \& Fuller, 1979, 1980). Moreover, fat enhances feed palatability and reduces dust (Lara et al., 2005).

Modern fast-growing broiler strains have high energy requirements, making oil addition to the diet almost mandatory due to its high energy concentration (Furlan \& Macari, 2002). Oils with high levels of polyunsaturated fatty acids (PUFA) are absorbed easier than those containing saturated fatty acids, and therefore have higher energy value and may promote better broiler performance (Dvorin et al., 1998). In addition, oils added to the feeds also supply essential fatty acids (Junqueira et al., 2005).

The live performance and meat quality obtained with the addition of oils that are sources of omega-3 polyunsaturated fatty acids (PUFA n-3) to broiler diets, coupled with the increasing consumers' concern with healthy diets, has promoted the use of these oils.

Excessive abdominal fat deposition is a concern for broiler producers, as part of the fat is lost during carcass evisceration, and may impair carcass quality and yield. Therefore, PUFA-rich oils may be an alternative to reduce abdominal fat deposition due to their high oxidation capacity (Sanz et al., 2000). 
Despite being a good PUFA source, soybean oil contains about $50-54 \%$ linoleic acid, which is an omega-6 PUFA (PUFA n-6; Martin et al., 2006).An alternative to increase the ratio of PUFA $n-3$ in the feed is to replace soybean oil by linseed oil, which contains more than $50 \%$ of $\alpha$-linolenic acid, which is a precursor of omega-3 fatty acids. Ajuyah et al. (1991) added different combinations of canola oil and linseed oil at 10 and $20 \%$ to the diet of male Hubbard broilers and observed higher lipid content in the white than in the dark meat in all diets and those fed 20\% linseed presented the lowest lipid deposition. Crespo \& EsteveGarcia (2001) fed broilers with a linseed oil-based diet and obtained 2.24 and $1.35 \%$ total lipids in the leg and breast, respectively.

This study was carried out to evaluate the effects of the inclusion of different linseed oil levels in iso-energy diets fed during the period of 21 to 56 days of age on the performance, carcass traits, and body composition of broilers.

\section{MATERIALS AND METHODS}

A total of 1600 male Cobb 500 broilers were housed in 32 pens in a masonry broiler house. Pens were equipped with semiautomatic tube feeders and bell drinkers. The 35-d experimental period was divided in two phases: Grower (21-42 days of age) and finisher (43-56 days of age). Broilers were vaccinated against Marek's disease, infectious bursal disease (IBD), and fowl pox at the hatchery, and on days 5 and 21 against IBD and on day 8 against Newcastle disease.

A lighting program of 24 hours of light was adopted during the entire experimental period. Environmental temperature was daily recorded. Average minimum and maximum temperatures during the experiment were $17^{\circ} \mathrm{C}$ and $30^{\circ} \mathrm{C}$, respectively.

During the starter period (1-21 days of age), birds were reared in an experimental broiler house and were fed a diet containing 3,005 kcal ME/kg and $21.6 \%$ crude protein to supply their nutritional requirements, according to the average of the recommendations of Rostagno et al. (2005) for the periods of 1-7 and 8-21 days of age. On day 21, broilers were weighed, selected according to the criterion of average weight per pen, and distributed according to a completely randomized experimental design consisting of four treatments (linseed oil levels) with eight replicates of 40 birds each.
The experimental diets contained equal nutritional levels in each phase and were formulated according to the recommendations of Rostagno et al. (2005). Diets were offered ad libitum as mash (Table 1). Linseed oil was included in the feed at the levels of $0.0,3.3,6.6$, and $9.9 \%$ iso-calorically replacing corn starch, whereas the levels of the other ingredients were maintained. In order to maintain equal nutritional levels, as determined by formulation, inert material needed to be added to the diets as oil levels increased.

At the end of each experimental phase and for the entire experimental period, weight gain (WG; g), feed intake ( $\mathrm{Fl} ; \mathrm{g})$, metabolizable energy intake (kcal), feed conversion ratio $(\mathrm{g} / \mathrm{g})$ and calorie conversion ratio $(\mathrm{kcal} / \mathrm{kg})$ were measured. Apparent metabolizable energy corrected for nitrogen balance (AMEn) of the diets used in each phases were determined in previous digestibility assays. Metabolizable energy intake ( $\mathrm{EI}=$ determined AMEn * $\mathrm{Fl}$ ) and calorie conversion ratio (CCR $=\mathrm{kcal}$ intake/kg WG) were calculated based on the AMEn values analyzed in feeds according to feeding phase. On days 42 and 56, two birds per replicate were randomly selected and sacrificed to determine carcass yield, breast yield, leg yield (thighs+drumstick) and abdominal fat percentage. Carcass yield was determined as the weight of the eviscerated carcass with no head, neck, and feet relative to broiler live weight. Parts yield and abdominal fat percentage (adipose tissue around the bursa, proventriculus, gizzard, and cloaca) were determined relative to the weight of the eviscerated carcass with no head, neck, and feet.

Body composition was determined in one bird with the average body of the replicate per replicate. After 24-h fasting, birds were sacrificed by neck dislocation, plucked, and their carcasses were ground and dried in a forced-ventilation oven at $55^{\circ} \mathrm{C}$ for 72 hours. After drying, samples were submitted to the determination of dry matter, crude protein, ether extract, and ash contents, according to the methodology described by Silva (1990).

The obtained data were submitted to analysis of variance using the software package Statistical Analysis System (SAS, 2002). When statistical significance was obtained, data were submitted to analysis of regression, considering dietary linseed oil as independent variable. Means were compared by the test of Tukey at $5 \%$ probability level. 
Table 1 - Ingredients and calculated nutritional composition of the experimental feeds supplied during the grower1 and the finisher2 phases.

\begin{tabular}{|c|c|c|c|c|c|c|c|c|}
\hline \multirow[t]{2}{*}{ Ingredients } & \multicolumn{4}{|c|}{$\begin{array}{l}\text { Linseed oil levels (\%) } \\
21 \text { to } 42 \text { days of age }\end{array}$} & \multicolumn{4}{|c|}{$\begin{array}{l}\text { Linseed oil levels }(\%)^{2} \\
43 \text { to } 56 \text { days of age }\end{array}$} \\
\hline & 0.0 & 3.3 & 6.6 & 9.9 & 0.0 & 3.3 & 6.6 & 9.9 \\
\hline Corn & 36.80 & 36.80 & 36.80 & 36.80 & 44.05 & 44.05 & 44.05 & 44.05 \\
\hline Soybean meal & 29.80 & 29.80 & 29.80 & 29.80 & 20.05 & 20.05 & 20.05 & 20.05 \\
\hline Corn gluten & 5.00 & 5.00 & 5.00 & 5.00 & 8.00 & 8.00 & 8.00 & 8.00 \\
\hline Linseed oil & 0.00 & 3.30 & 6.60 & 9.90 & 0.00 & 3.30 & 6.60 & 9.90 \\
\hline Corn starch & 24.00 & 16.00 & 8.00 & 0.00 & 24.00 & 16.00 & 8.00 & 0.00 \\
\hline Dicalcium phosphate & 2.25 & 2.25 & 2.25 & 2.25 & 1.85 & 1.85 & 1.85 & 1.85 \\
\hline Limestone & 1.19 & 1.19 & 1.19 & 1.19 & 1.05 & 1.00 & 1.00 & 1.00 \\
\hline Salt & 0.30 & 0.30 & 0.30 & 0.30 & 0.30 & 0.30 & 0.30 & 0.30 \\
\hline DL-Methionine (99\%) & 0.16 & 0.16 & 0.16 & 0.16 & 0.08 & 0.08 & 0.08 & 0.08 \\
\hline L-Lysine HCL (78.5\%) & - & - & - & - & 0.11 & 0.11 & 0.11 & 0.11 \\
\hline Rice hulls & 0.00 & 4.70 & 9.40 & 14.10 & 0.00 & 4.75 & 9.45 & 14.15 \\
\hline Vit. + min. supplement*/** & 0.50 & 0.50 & 0.50 & 0.50 & 0.50 & 0.50 & 0.50 & 0.50 \\
\hline Total & 100.00 & 100.00 & 100.00 & 100.00 & 100.00 & 100.00 & 100.00 & 100.00 \\
\hline \multicolumn{9}{|l|}{ Calculated values } \\
\hline $\mathrm{ME}(\mathrm{kcal} / \mathrm{kg})$ & 2998 & 2998 & 2998 & 2998 & 3131 & 3131 & 3131 & 3131 \\
\hline $\mathrm{CP}(\%)$ & 20.00 & 20.00 & 20.00 & 20.00 & 18.00 & 18.00 & 18.00 & 18.00 \\
\hline $\mathrm{Ca}(\%)$ & 1.07 & 1.07 & 1.07 & 1.07 & 0.90 & 0.90 & 0.90 & 0.90 \\
\hline Avail. phosphorus (\%) & 0.512 & 0.512 & 0.512 & 0.512 & 0.427 & 0.427 & 0.427 & 0.427 \\
\hline Lysine (\%) & 1.00 & 1.00 & 1.00 & 1.00 & 0.85 & 0.85 & 0.85 & 0.85 \\
\hline Met. + cys (\%) & 0.83 & 0.83 & 0.83 & 0.83 & 0.72 & 0.72 & 0.72 & 0.72 \\
\hline
\end{tabular}

${ }^{1}$ Grower. Supplied per kg feed: Vit. A 1500 IU/kg, Vit E 20 mg, Vit. K 0.5 mg, Vit. B, 2 mg. Vit B, 3.6 mg, Vit. B 20 mcg, calcium pantothenate 10 mg, folic acid 0.5 mg, growth promoter $50 \mathrm{mg}$, niacin $100 \mathrm{mg}$, copper $75 \mathrm{mg}$, iodine $1.25 \mathrm{mg}$, selenium $0.25 \mathrm{mg}$, manganese $120 \mathrm{mg}$, zinc $100 \mathrm{mg}$, iron $50 \mathrm{mg}$, antioxidant $0.5 \mathrm{mg}$ coccidicide $110 \mathrm{mg} .{ }^{2}$ Finisher. Supplied per kg feed: Vit. A $1500 \mathrm{IU} / \mathrm{kg}$, Vit E $1 \mathrm{mg}$, Vit. K 0.49 mg, Vit. B 2 mg. Vit B 1.75 mg, Vit. B 5 mcg, calcium pantothenate 10 mg, folic acid 0.25 mg, growth promoter 15 mg, niacin $100 \mathrm{mg}$, copper $75 \mathrm{mg}$, iodine $1.25 \mathrm{mg}$, selenium $0.25 \mathrm{mg}$, manganese $120 \mathrm{mg}$, zinc $100 \mathrm{mg}$, iron $50 \mathrm{mg}$, antioxidant $0.625 \mathrm{mg}$ coccidicide $125 \mathrm{mg}$.

\section{RESULTS AND DISCUSSION}

Linseed inclusion level had a quadratic influence $(p<0.05)$ on broiler WG during the period of 21 to 42 days $(W G=1.450 .852+43.10122 X-2.23735 X 2 ; R 2$ $=0.98$; Table 2), up to $9.63 \%$ dietary inclusion. This result is consistent with the findings of Lopez-Ferrer et al. (2001b), who added different linseed oil and tallow ratios to Cobb broiler diets and observed higher weight gain in those fed high linseed oil levels. On the other hand, Almeida et al. (2009), replaced soybean oil by linseed oil in the diet of male and female Cobb broilers and did not observe any influence of lipid source on feed intake, weight gain or feed conversion ratio $(P>0.05)$. Murakami et al. (2010) found lower weight gain when broilers were fed 6.5 and $4.95 \%$ linseed oil in the periods of 1-21 and 22-49 days of age, respectively.

However, in the period of 21-56 days, the analysis of regression showed that increasing linseed oil levels linearly increased broiler weight gain (WG $=2.561 .463$ $+27.3078 X ; R 2=0.90 ; p<0.01)$. Consistent results were obtained by Lopéz-Ferrer et al. (2001b), who added different linseed oil to tallow ratios in the diet of Cobb broilers and reported higher weight gain as linseed oil levels increased.

Crespo \& Esteve-Garcia (2002c) fed broilers with diets containing tallow, olive oil, sunflower oil, and linseed oil also found higher weight gain and better feed conversion ratio compared to a basal diet during the phase of 28-53 days of age.

Although the experimental diets were iso-caloric, the analysis of regression for feed intake (FI) showed a significant lineal increase both in the periods of 21-42 days $(F I=2.965 .1049+21.953 X ; R 2=0.95$; $\mathrm{p}<0.01)$ and $21-56$ days $(\mathrm{FI}=5.826 .813+22.069 \mathrm{X}$; $R 2=0.90 ; p<0.05)$, as shown in Table 2 . These results are consistent with those of Murakami et al. (2009), who observed a quadratic increase in feed intake in the period of 1-7 days with increasing dietary linseed oil levels, with an estimated maximum level of $4.6 \%$. Also Lopez-Ferrer et al. (1999) compared the feed intake of Cobb broilers fed diets supplemented with $8.2 \%$ fish oil or $8.2 \%$ linseed or canola oil and obtained higher daily $\mathrm{Fl}$ in those fed vegetable oils. On the other hand, Murakami et al. (2010) observed feed intake reduction when broilers were fed linseed oil, which, according to 
Almeida et al. (2009), may be attributed to organoleptic differences between linseed oil and soybean oil.

Pucci et al. (2003) also found that the dietary inclusion of up to $7.5 \%$ of soybean oil linearly increased feed intake of broilers in the periods of 1-21 and 2242 days of age. On the other hand, Tabeeidian et al. (2005) observed lower feed intake when broilers were fed $7.5 \%$ soybean oil in the period of 7-21 days of age.

Dietary linseed oil inclusion levels had a quadratic influence $(p<0.05)$ on feed conversion ratio (Table 2 ) in both studied periods, as shown by the equations $F C R=1.9342-0.032015 X+0.0020349 X 2, R 2=0.92$ and $F C R=2.1884-0.03445 X+0.00203547 X 2, R 2$ $=0.90$, up to the levels of 7.87 and $8.46 \%$ for the periods of 21-42 and 21-56 days of age, respectively. This behavior may be related to the linear increase in feed intake without the corresponding increase in weight gain. These results are consistent with those of Murakami et al. (2009), who included increasing linseed oil levels in broiler diets during the period of 1-43 days of age and observed a linear improvement in feed conversion ratio, demonstrating the beneficial effects of this oil source on broiler performance. However, in a subsequent study, Murakami et al (2010) found that feed conversion ratio worsened when linseed oil was fed during the starter phase (1-21 days) and no effect thereafter (22-49 days).

Table 2 - Weight gain (WG), feed intake (FI), metabolizable energy intake1 (MEI), feed conversion ratio (FCR), and calorie conversion ratio (CCR) of broilers fed four linseed oil level during the phases of 21-42 and 21-56 days of age.

\begin{tabular}{|c|c|c|c|c|c|}
\hline \multirow{2}{*}{$\begin{array}{l}\text { Linseed oil } \\
\text { levels (\%) }\end{array}$} & \multicolumn{5}{|c|}{$21-42$ days of age } \\
\hline & WG $(g)^{3}$ & $\mathrm{FI}(\mathrm{g})^{4}$ & $\mathrm{CA}^{3}$ & $\mathrm{CE}(\mathrm{kcal})^{4}$ & $\mathrm{CC}(\mathrm{kcal} / \mathrm{kg})^{3}$ \\
\hline 0.0 & 1.451 .60 & 2.956 .40 & 1.94 & 8.869 .20 & 6.11 \\
\hline 3.3 & 1.564 .65 & 3.029 .55 & 1.84 & 9.155 .30 & 5.85 \\
\hline 6.6 & 1.641 .60 & 3.147 .35 & 1.82 & 9.555 .35 & 5.82 \\
\hline 9.9 & 1.656 .80 & 3.159 .70 & 1.81 & 9.542 .29 & 5.76 \\
\hline$P$ values & 0.0035 & $<0.0001$ & $<0.0001$ & $<0.0001$ & 0.0006 \\
\hline CV (\%) & 3.05 & 2.26 & 1.51 & 2.27 & 2.08 \\
\hline \multirow{2}{*}{$\begin{array}{l}\text { Linseed oil } \\
\text { levels (\%) }\end{array}$} & \multicolumn{5}{|c|}{$21-56$ days of age } \\
\hline & WG $(g)^{4}$ & $\mathrm{FI}(\mathrm{g})^{4}$ & $\mathrm{CA}^{3}$ & CE $(\mathrm{kcal})^{4}$ & $\mathrm{CC}(\mathrm{kcal} / \mathrm{kg})^{3}$ \\
\hline 0.0 & 2.532 .70 & 5.833 .95 & 2.19 & 18.289 .43 & 7.22 \\
\hline 3.3 & 2.682 .80 & 5.867 .20 & 2.08 & 18.552 .09 & 6.91 \\
\hline 6.6 & 2.764 .50 & 6.013 .50 & 2.07 & 18.744 .08 & 6.78 \\
\hline 9.9 & 2.805 .35 & 6.027 .75 & 2.04 & 18.517 .25 & 6.60 \\
\hline Valores de P & $<0.0001$ & 0.0014 & $<0.0001$ & 0.050 & 0.0011 \\
\hline CV (\%) & 2.77 & 2.98 & 1.37 & 3.00 & 1.36 \\
\hline
\end{tabular}

${ }^{1}$ Determined AMEn values (calculated values) on day 22: 3000 (2998), 3022 (2998),

3036 (2998), and 3020 (2998) kcal/g MN. On day 42: 3135 (3131), 3162 (3131),

3117 (3131), and 3072 (3131) kcal/g MN.

${ }^{2}$ Calculated considering the AMEn values determined in digestibility assay.

NS - not significant; ${ }^{3}$ quadratic effect; ${ }^{4}$ quadratic effect; CV - coefficient of variation.
Zelenka et al. (2006) verified better feed intake, weight gain and feed conversion ratio in broilers fed 5 and $7 \%$ linseed oil compared to those fed 1 and $3 \%$ between 20 and 40 days of age. Crespo \& EsteveGarcia (2002c) also found better feed conversion ratio in broilers fed diets containing tallow, olive oil, sunflower oil, and linseed oil during the phase of 2853 days of age.

The linear increase in weight gain may be explained by the linear increase in metabolizable energy intake, as shown by the equations $\mathrm{MEI}=9,392.465+76.74 \mathrm{X}$; $R 2=0.88 ;(p<0.01)$ for the period of 21-42 days and $\mathrm{MEI}=18,898.30+56.118 X ; R 2=0.75(p=0.05)$ for the period of 21-56 days. The results obtained for the total experimental period show that the replacement of carbohydrates by fat as energy source promoted better live performance, demonstrating the superiority of fats relative to carbohydrates. On the other hand, Plavnik et al. (1997) did not obtain clear evidences suggesting any superiority of fat relative to carbohydrates as energy source in terms of weight gain, feed intake or feed conversion ratio of broilers of different ages.

Linseed oil levels had a quadratic influence $(p<0.05)$ on calorie conversion ratio (Table 2 ), as shown by equations $C C R=5,8004-0.074746 X+0.0043054 X 2$; $R 2=0.90(p<0.05)$ e $C C R=6,6998-0.083695 X+$ $0.0036708 \times 2 ; R 2=0.92(p<0.05)$ up to the levels of 8.68 and $11.40 \%$ for the periods of $21-42$ and $22-56$ days, respectively.

Average carcass yield, breast yield, and leg yield determined when broilers were 42 days old were not influenced ( $p>0.05$ ) by linseed oil dietary level (Table 3), as previously found by Almeida et al. (2009). However, the analysis of regression revealed a quadratic effect on abdominal fat percentage $(\mathrm{AF}=1.9193+0.1798 \mathrm{X}$ $\left.0.01313 \times 2 ; R^{2}=0.99 ; p<0.05\right)$, estimating a maximum level of $6.85 \%$ linseed oil. When broilers were 56 days old (Table 3), dietary linseed oil levels had a quadratic influence on abdominal fat $(\mathrm{AF}=2.20+0.1897 \mathrm{X}$ $\left.0.0155 \times 2 ; R^{2}=0.77 ; p<0.05\right)$, at a maximum inclusion level of $6.12 \%$. These results are different from those of Murakami et al. (2010), who found that broilers fed linseed oil deposited less abdominal fat when fed soybean oil during the phase of 1-49 days of age. According to those authors, abdominal fat deposition can be changed as a function of dietary fatty acid profile. Crespo \& Esteve-Garcia (2001) also observed lower abdominal fat deposition when broilers were fed linseed oil.

According to Crespo \& Esteve-Garcia (2002b), this lower abdominal fat deposition in broilers fed PUFA- 
rich diets is due to the high oxidation capacity of those acids. In addition, poly-unsaturated fatty acids, particularly n-3 acids, are preferably deposited as membrane phospholipids, differently from saturated fatty acids, which, if consumed in excess, are deposited as triglycerides in fatty tissues (Ponnampalam et al., 2001).

Table 3 - Carcass yield (CY), breast yield (BY), leg yield (LY), and abdominal fat percentage (AF) of broilers fed four linseed oil levels during the phases of 21-42 and 21-56 days of age.

\begin{tabular}{|c|c|c|c|c|}
\hline \multirow{2}{*}{$\begin{array}{l}\text { Linseed oil } \\
\text { levels (\%) }\end{array}$} & \multicolumn{4}{|c|}{42 days of age } \\
\hline & CY (\%) & BY (\%) & LY (\%) & $\operatorname{AF}(\%)^{1}$ \\
\hline 0.0 & 64.6 & 33.15 & 29.73 & 1.82 \\
\hline 3.3 & 64.6 & 32.68 & 30.30 & 2.22 \\
\hline 6.6 & 64.31 & 32.96 & 29.83 & 2.43 \\
\hline 9.9 & 64.12 & 32.58 & 29.35 & 2.28 \\
\hline$P$ values & $0.0836^{\mathrm{NS}}$ & $0.0759^{\mathrm{NS}}$ & $0.0842^{\mathrm{NS}}$ & $0.036 *$ \\
\hline CV (\%) & 1.60 & 3.60 & 3.90 & 22.99 \\
\hline \multirow{2}{*}{$\begin{array}{l}\text { Linseed oil } \\
\text { levels }{ }^{1} \\
\text { de linhaça } \\
(\%)\end{array}$} & \multicolumn{4}{|c|}{56 days of age } \\
\hline & CY (\%) & BY (\%) & LY (\%) & $\operatorname{AF}(\%)^{1}$ \\
\hline 0.0 & 68.67 & 30.56 & 30.29 & 2.14 \\
\hline 3.3 & 67.26 & 32.00 & 30.056 & 2.37 \\
\hline 6.6 & 67.62 & 31.58 & 29.91 & 2.79 \\
\hline 9.9 & 68.29 & 31.67 & 29.89 & 2.36 \\
\hline$P$ values & $0.0941^{\mathrm{NS}}$ & $0.0657^{\mathrm{NS}}$ & $0.0893^{N S}$ & $0.015^{*}$ \\
\hline CV (\%) & 2.49 & 4.62 & 3.95 & 21.39 \\
\hline
\end{tabular}

NS - not significant; ${ }^{1}$ quadratic effect; CV - coefficient of variation.

Cortinas et al. (2004) added different PUFA and vitamin $E$ levels to Ross broiler diets and found that vitamin $E$ and PUFA did not influence breast weight, but leg yield relative of eviscerated carcass weight tended to improve with increasing dietary PUFA levels.

Analyzing the obtained results, the quadratic influence of linseed oil dietary inclusion on abdominal fat determined on days 42 and 56 is possibly related to the quadratic behavior observed on weight gain during the period of 21 to 42 days of age.

There was no effect ( $p>0.05$ ) of linseed oil inclusion levels on carcass moisture, crude protein, dry matter or ash content of the carcasses of 56 -d-old broilers, differently from the findings of Murakami et al. (2010), who obtained significant reduction of moisture content in the leg of broilers fed linseed oil. However, linseed oil levels linearly increased ether extract content $(E E=$ $37.74+0.275 X ; R 2=0.70 ; p<0.05)$, showing that as carbohydrates were replaced by linseed oil, body fat deposition increased. This suggests that there is a limit for abdominal fat deposition, after which the excess of fat is directed to other carcass parts.
Table 4 - Dry matter $(D M)$, humidity $(H)$, crude protein $(C P)$, ether extract (EE), and ash (A) contents(AF) of the carcasses of broilers fed four linseed oil level during the phases of 21-42 and 21-56 days of age.

\begin{tabular}{lccccc}
\hline $\begin{array}{l}\text { Linseed } \\
(\%)\end{array}$ & $\begin{array}{c}\mathrm{DM} \\
(\%)\end{array}$ & $\begin{array}{c}\mathrm{H} \\
(\%)\end{array}$ & $\begin{array}{c}\mathrm{CP} \\
(\%)\end{array}$ & $\begin{array}{c}\mathrm{EE}^{1} \\
(\%)\end{array}$ & $\begin{array}{c}\text { Ash } \\
(\%)\end{array}$ \\
\hline 0.0 & 32.26 & 62.74 & 46.27 & 38.40 & 6.34 \\
\hline 3.3 & 33.15 & 61.84 & 46.82 & 38.20 & 6.40 \\
\hline 6.6 & 34.03 & 60.97 & 45.35 & 38.72 & 6.59 \\
\hline 9.9 & 33.38 & 61.62 & 45.30 & 41.14 & 6.47 \\
\hline P values & $0.0833^{\mathrm{NS}}$ & $0.0659^{\mathrm{NS}}$ & $0.0542^{\mathrm{NS}}$ & 0.00125 & 0.0426 \\
\hline CV (\%) & 3.92 & 2.14 & 5.22 & 5.55 & 8.15 \\
\hline
\end{tabular}

*Values expressed on 100\% DM; NS - not significant; ' 'Linear effect; CV - coefficient of variation

These results are different from those of Laurin et al. (1985), who fed three broiler strains with isocalorie and iso-protein diets with 2 or $9 \%$ fat and did not find any increase in body fat deposition. On the other hand, Deaton et al. (1981) fed broilers with diets containing 4, 7 or $10 \%$ animal fat and verified that abdominal fat and carcass fat deposition increased as dietary fat content increased.

The observed increase in body fat content may be attributed to the linear increase in energy intake, supplying energy in excess of bird requirements that was deposited in other body parts, as abdominal fat percentage presented a quadratic behavior.

\section{CONCLUSIONS}

The dietary addition of linseed oil presents variable effects on broiler performance and carcass traits; however, considering feed conversion ratio as an important parameter, maximum linseed oil inclusion levels of $7.86 \%$ for the period of $21-42$ days and of $8.46 \%$ for the period of $21-56$ days were calculated. Nevertheless, linseed oil inclusion levels higher than $6.85 \%$ and $6.12 \%$ increase abdominal fat percentage in the carcasses of 42- and 56-d-old broilers, respectively. In addition, linseed oil dietary inclusion may linearly increase carcass ether extract content.

\section{REFERENCES}

Ajuyah AO, Lee KH, Hardin RT, Sim JS. Changes in the yield and in the fatty acid composition of whole carcass and selected meat portions of broiler chickens fed full-fat oil seeds. Poultry Science 1991;70(11):2304-2314.

Almeida APS, Pinto MF, Poloni LB, Ponsano EHG, Garcia Neto M. Efeito do consumo de óleo de linhaça e de vitamina E no desempenho e nas características de carcaças de frangos de corte. Arquivo Brasileiro de Medicina Veterinária e Zootecnia 2009;61 (3):698-705. 
Cortinas L, Villaverde C, Galobart J, Baucells MD, Codony R, Barroeta AC. Fatty acid content in chickens thigh and breast as affected by dietary polyunsaturated level. Poultry Science 2004;83(7):1155-1164

Crespo N, Esteve-Garcia E. Dietary fatty acid profile modifies abdominal fat deposition in broiler chickens. Poultry Science 2001;80(1):71-78.

Crespo N, Esteve-Garcia E. Dietary polyunsaturated fatty acids decrease fat deposition in separable fat depots but not in the remainder carcass. Poultry Science 2002a; 81(4):512-518.

Crespo N, Esteve-Garcia E. Nutrient and fatty acid deposition in broilers fed different dietary fatty acid profiles. Poultry Science 2002b;81(10):15351544.

Crespo N, Esteve-Garcia E. Dietary linseed oil produces lower abdominal fat deposition but higher de novo fatty acid synthesis in broiler chickens. Poultry Science, 2002c; 81(10):1555-1562.

Dale NM, Fuller HL. Effect of diet composition on feed intake and growth of chicks under heat stress II. Cosntant vs cycling temperature. Poultry Science 1980;59(7):1434 - 1441

Dale NM, Fuller HL. Effect of diet composition on feed intake and growth of chicks under heat stress I. Dietary fat levels. Poultry Science 1979;58(6):1529-1534.

Deaton JW, McNaughton JL, Reece FN, Lott BD. Abdominal fat of broilers as influenced by dietary level of animal fat. Poultry Science $1981 ; 60(6): 1250-1253$.

Dutra Junior WM, Ariki J, Kronka SN, Junqueira OM. Óleo de abatedouro avícola em comparação ao óleo de soja na alimentação de frangos de corte. Revista Brasileira de Zootecnia 1991;20(5):471-475

Dvorin A, Zoref Z, Mokady S, Nitsan Z. Nutritional aspects of hidrogenated and regular soybean oil added to diets of broiler chicks. Poultry Science 1998;77(6):820-825

Furlan RL, Macari M. Lipídios: digestão e absorção. In: Macari M, Furlan RL, Gonzáles E. Fisiologia aviária aplicada a frangos de corte. Jaboticabal: FUNEP; 2002. Cap. 11, p. 143.

Gaiotto, JB, Menten JFM, Racanicci AMC. Óleo de soja, óleo ácido de soja e sebo bovino como fontes de gordura em rações de frangos de corte. Revista Brasileira de Ciência Avícola 2000;2(3):219-228.

Junqueira OM, Andreotti MO, Araújo LF, Duarte KF, Cancherini LC, Rodrigues EA. Valor energético de algumas fontes lipídicas determinado com frangos de corte. Revista Brasileira de Zootecnia 2005;34(6):23352339.

Lara LJC, Baião NC, Aguilar CAL, Cançado SV, Fiuza MA, Ribeiro BRC. Efeito de fontes lipídicas sobre o desempenho de frangos de corte. Arquivo Brasileiro de Medicina Veterinária e Zootecnia 2005;57(6):792-798.

Laurin DE, Touchburn SP, Chavez ER, Chan CW. Effect of dietary fat supplementation on the carcass composition for three genetic lines of broilers. Poultry Science 1985; 64(11):2131-2135.

Lopez-Ferrer S, Baucells MD, Barroeta AC, Grashorn MA. n-3 enrichment of chicken meat. 1. Use of very long-chain fatty acids in chicken diets and their influence on meat quality: fish oil. Poultry Science 2001a;80(6):741-752.

Lopez-Ferrer S, Baucells MD, Barroeta AC, Galobart J, Grashorn MA. n-3 enrichment of chicken meat. 2. Use of precursors of long- chain polyunsaturated fatty acids: linseed oil. Poultry Science 2001b;80(6):753-761

Lopez-Ferrer S, Baucells MD, Barroeta AC, Grashorn MA. n-3 enrichment of chicken meat using fish oil: alternative substitution with linseed and linseed oils. Poultry Science 1999;78(3):356-365.

Martin CA, Almeida VV, Ruiz MR, Visentainer JEL, Matsushita M, Souza NE, Visentainer JV. Ácidos graxos poliinsaturados ômega-3 e ômega-6: importância e ocorrência em alimentos. Revista de Nutrição de Campinas 2006;19:761-770

Murakami A E, Garcia ERM, Martins EM, Moreira I, Scapinello C, Oliveira AFG. Efeito da inclusão de óleo de linhaça nas rações sobre o desempenho e os parâmetros ósseos de frangos de corte. Revista Brasileira de Zootecnia 2009;38(7):1256-1264.

Murakami KTT, Pinto MF, Ponsano EHG, Garcia Neto M. Desempenho produtivo e qualidade da carne de frangos alimentados com ração contendo óleo de linhaça. Pesquisa Agropecuária Brasileira 2010:45(4):401-407.

Plavnik E, Wax D, Sklan D, Bartov I, Hurwitz S. The response of broiler chickens and turkey poults to dietary energy supplied either by fat or carbohydrates. Poultry Science 1997;76(7):1000-1005.

Ponnampalam EN, Sinclair AJ, Egan AR, Blakeley SJ, Li D, Leury BJ. Effect of dietary modification of muscle long chain n-3 fatty acid on plasma insulin and lipid metabolites, carcass traits, and fat deposition in lambs. Journal of Animal Science, 2001;79(4):895-903.

Pucci LEA, Rodrigues PB, Freitas RTF, Bertechini AG, Carvalho EM. Níveis de óleo e adição de complexo enzimático na ração de frangos de corte. Revista Brasileira de Zootecnia 2003;32(4):909-917.

Rodriguez ML, Ortiz LT, Alzueta C, Rebole A, Trevino J. Nutritive value of high-oleic acid sunflower seed for broiler chickens. Poultry Science 2005; 84(3):395-402

Rostagno HS, Albino LFT, Donzele JL, Gomes PC, Oliveira RF, Lopes DC, Ferreira AS, Barreto SLT. Tabelas brasileiras para aves e suínos: composição de alimentos e exigências nutricionais. 2nd ed. Viçosa: UFV; 2005.

Sanz M, Flores A, De Ayala PP, Lopez-Bote CJ. Higher lipid accumulation in broilers fed on saturated fats than in those fed on unsaturated fats. British Poultry Science 1999; 40(1):95-101

Sanz M, Lopez-Bote CJ, Menoyo D, Bautista JM. Abdominal fat deposition and fatty acid synthesis are lower and beta-oxidation is higher in broiler chickens fed diets containing unsaturated rather than saturated fat. Journal of Nutrition 2000; 130(12):3034-3037

SAS Institute. SAS System for Microsoft Windows, Release 6.12. Cary; 2002

Silva DJ. Análise de alimentos (Métodos químicos e biológicos). 2nd ed Viçosa: Universidade Feeral de Viçosa, Imprensa Universitária; 1990.

Tabeeidian A, Sadeghi GH, Pourreza J. Effect of dietary protein levels and soybean oil supplementation on broilers performance. International Journal of Poultry Science, 2005;4(10):799-803.

Zelenka J, Schneiderová D, Mrkvicová E. Linseed oils with different fatty acid patterns in the diet of broiler chickens. Czech Journal of Animal Science 2006:51(3):117-121. 